\title{
CHANGES IN THE ULTRASTRUCTURE OF CAPSICUM ANNUUM L. SEEDLINGS ROOTS UNDER ALUMINUM STRESS CONDITIONS
}

\author{
Agata Konarska \\ Department of Botany, University of Life Sciences in Lublin, Akademicka 15, 20-950 Lublin \\ e-mail: agata.konarska@ar.lublin.pl
}

Received: 14.03 .2008

S u m m a r y

The effect of aluminum was investigated on the cell ultrastructure of roots of fourteen-day-old 'Trapez' red pepper seedlings grown in water culture. Disorders in the cell structure were observed using transmission electron microscopy (TEM). An analysis of longitudinal sections of the apical region of the control plants' roots showed that cells of the cap and cells of the meristematic region had an arrangement and shape typical for these root regions, and cell organelles were properly developed.

Changes in the cell structure under the influence of aluminum involved a reduction in the number of starch grains in the leucoplasts of the cap, the formation of lobate nuclei and a reduction in the number of cisternae in the dictyosomes as well as the damage of the cell membranes. Moreover, the swelling of mitochondria was observed with a simultaneous reduction in the number of mitochondrial cristae or the bursting of the membrane of these structures. In the vacuoles of the investigated root section, the presence of numerous electron-opaque large-sized formations was found, being most probably aluminum deposits. The cell wall, often thickened, was wavy or the formation of two walls in close distance was observed. The obtained results prove the high sensitivity of the studied red pepper cultivar to aluminum stress.

Key words: root, ultrastructure, aluminum, Capsicum annuum

\section{INTRODUCTION}

Most plants respond to the presence of mobile aluminum in the substrate by a significant limitation of growth and yielding induced by development anomalies and metabolic disturbances as well as by insufficient supply of the plant with water and nutrients. Studies of many authors have demonstrated that the greatest disorders occur in the place of toxicant application, i.e. in the root, in particular in its apical portion $(\mathrm{C}$ l u n e and Copeland, 1999; M i chałek, 2002; Konar$\mathrm{ska}, 2004 \mathrm{a})$. The most characteristic morphological symptoms of aluminum toxicity are as follows: the shortening of the length of roots, their thickening and brown- ing as well as the bending of the terminal section of the root (Weryszko-Chmielewska et al. 1999; Malathi et al. 2001; Tabuchi and Matsumoto,2001; Konarska,2004b; 2005). Many researchers also observed peeling off or falling off of the cap as well as a reduction in the length of lateral roots (Budiková, 1999; Wenzl et al. 2001). The effect of aluminum was frequently accompanied by the shortening of root regions and of the length of root hairs as well as their deformation ( $\mathrm{S} z$ a t a $\mathrm{n} \mathrm{i} \mathrm{k}-\mathrm{K} \mathrm{lo} \mathrm{c}$, 1999; Mic hałe k, 2002). An increased thickness of cell walls in the outer layers of the root was also observed, as well as the formation of cracks and losses in these tissues (Weryszko-Chmielewska and Chwi1, 1998; Budiková, 1999; Vázquez et al. 1999; K on ars ka, 2005). At the cell level, strong vacuolisation of cells, a decrease in the number of endoplasmic reticulum tubules and a reduced number of vesicles produced by Golgi bodies were a frequent reaction to excess aluminium (De Lima and C o p e land, 1994; B e nnet, 1998). In the presence of aluminum ions, the programmed death of PCD cells was also observed ( $\mathrm{Pan}$ et al. 2001), as well as the disintegration of microtubules and a change in polymerisation of the cytoskeleton (Horst et al. 1999; Sivaguru et al. 1999).

The purpose of this study was to determine the effect of aluminum on the cell ultrastructure of the apical portion of roots of red pepper cv. 'Trapez' using transmission electron microscopy.

\section{MATERIALS AND METHODS}

Red pepper (Capsicum annuum L.) seedlings cv. 'Trapez' were cultivated in plastic containers $4 \mathrm{dm}^{3}$ in capacity which were filled with modified Knop's nutrient solution (Brauner and Bunkats h 1987). Aluminum was added as $\mathrm{AlCl}_{3} \times 6 \mathrm{H}_{2} \mathrm{O}$ at two concentrations: 0 (control) and $20 \mathrm{mg} \times \mathrm{dm}^{-3}$ of the medium, what corre- 

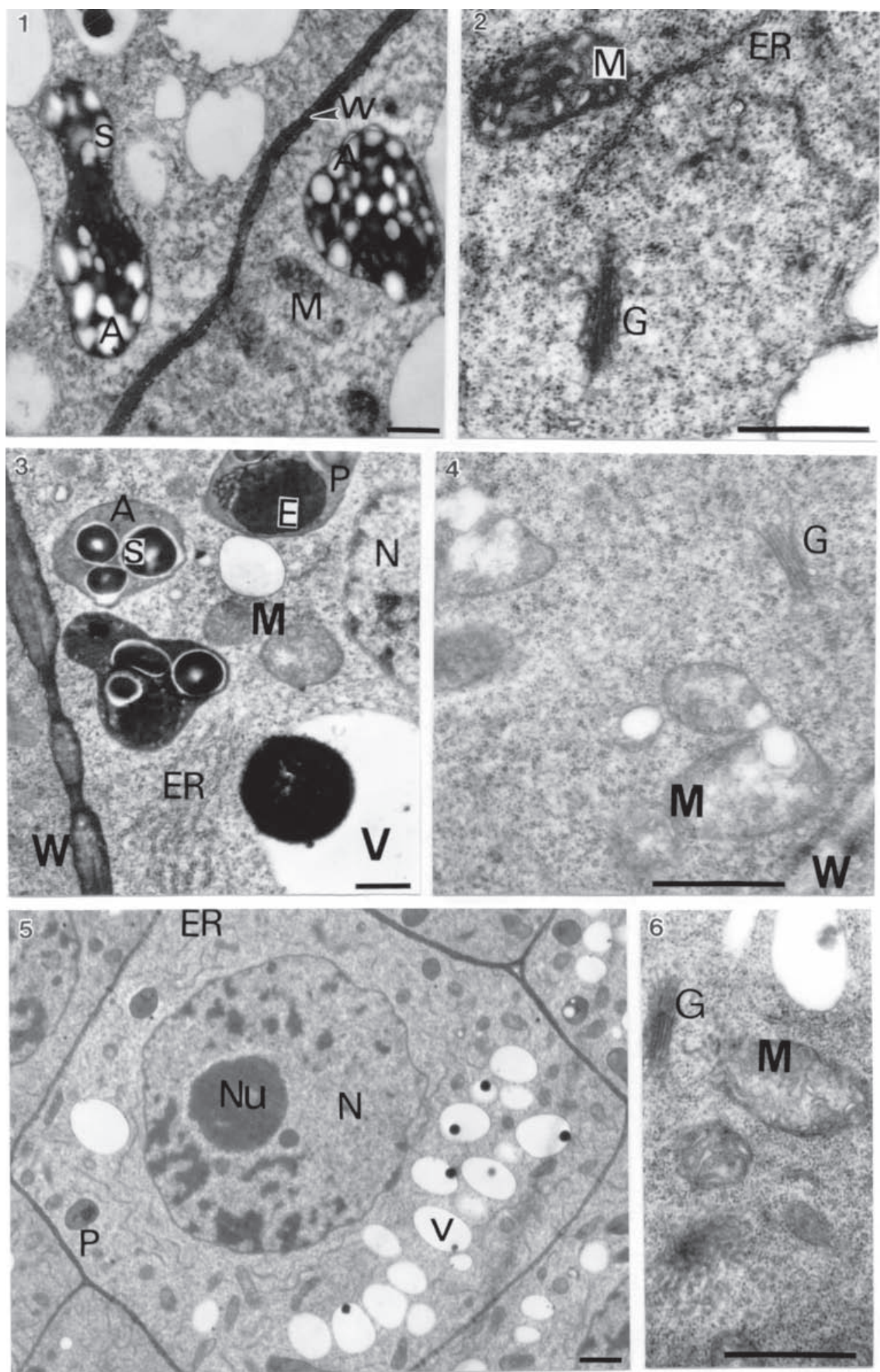

Figs 1-4. Fragments of cells of the root cap of red pepper seedlings seen in TEM: 1,2-control; visible small vacuoles (V), mitochondria with numerous mitochondrial cristae (M) and amyloplasts (A) with numerous starch grains (S). 3, $4-20 \mathrm{mg}^{\prime} \mathrm{dm}^{-3} \mathrm{AlCl}_{3}$; visible rounded mitochondria (M) often with degenerating contents, a vacuole (V) with a dark deposits (D) and amyloplasts (A) with large starch grains (S). Bars $=1 \mu \mathrm{m} . \mathrm{N}$ - cell nucleus, ER - endoplasmic reticulum, $\mathrm{P}$ - proplastid, $\mathrm{G}-\mathrm{Golgi}$ body, $\mathrm{W}$ - cell wall, E - electron dense structures.

Figs 5, 6. Cells of the meristematic region of the root of 14-day-old red pepper seedlings in the control; visible a cell nucleus (N) with a nucleolus $(\mathrm{Nu})$, numerous mitochondria $(\mathrm{M})$, proplastids $(\mathrm{P})$, small vacuoles $(\mathrm{V})$, endoplasmic reticulum $(\mathrm{ER})$ and a Golgi body (G). Bar $-2 \mu \mathrm{m}$ (Fig. 5), bar $-1 \mu \mathrm{m}$ (Fig. 6). 

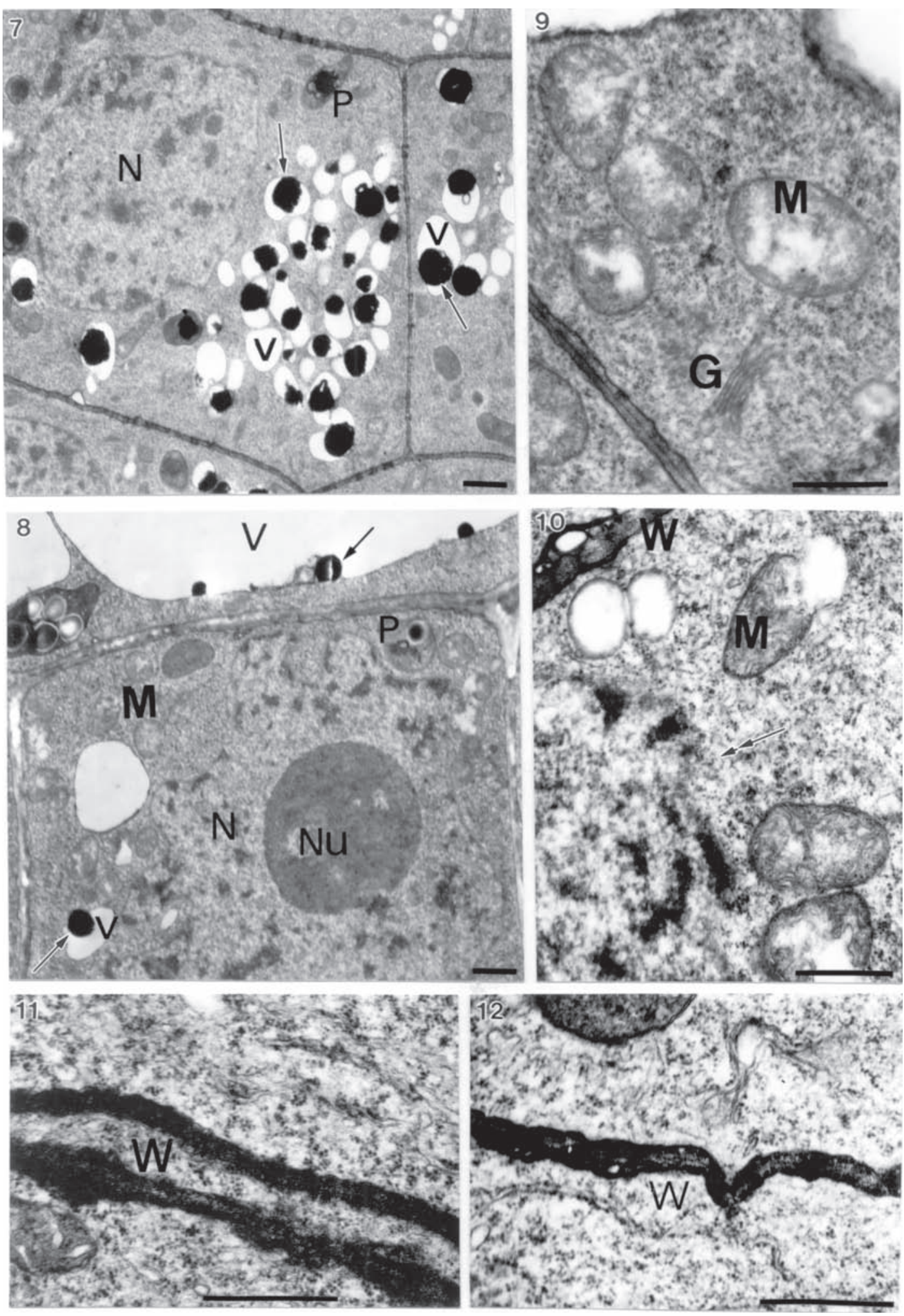

Figs 7-12. Fragments of meristematic cells of the root of 14-day-old red pepper seedlings in the presence of $20 \mathrm{mg}^{\prime} \mathrm{dm}^{-3} \mathrm{AlCl}_{3}$. Cell protoplasts show a high degree of vacuolisation. Note dark bodies in the vacuoles (arrows) $(7,8)$, an irregular-shaped, lobate cell nucleus (8), enlarged mitochondria with degenerating contents or disrupted membrane $(9,10)$ and a partial degradation of the nucleus membrane (double arrow) (10), as well as disturbances in the form of two cell wells formed at a close distance (11) and folds of the cell wall (12), $\mathrm{N}$ - cell nucleus, $\mathrm{M}$ - mitochondria, $\mathrm{V}$ - vacuole, $\mathrm{W}$ - cell wall, $\mathrm{P}$ - proplastids, $\mathrm{G}-$ Golgi body. Bars $=2 \mu \mathrm{m}$ (Figs 7, 8), bars $=1 \mu \mathrm{m}$ (Figs 9-12). 
sponds to 0 and $1.1 \mathrm{mg}_{\times} \mathrm{dm}^{-3}$ of pure aluminum. The $\mathrm{pH}$ of the solutions was set to 4.3 by using $0.1 \mathrm{M} \mathrm{HCl}$ or 0.1 $\mathrm{M} \mathrm{NaOH}$. Disinfected seeds of tested plant germinated on wet filterpaper of Petri dishes. After four days from germination, the seedlings were transferred to water culture. Each treatment comprised 30 plants cultured for fourteen days. During the experiment, the nutrient solution was aerated and its depletion was supplemented, and after a week it was replaced. The experiment was carried out in a phytotron under a 14-hour photoperiod, at a temperature of $24^{\circ} \mathrm{C} \pm 1^{\circ} \mathrm{C}$ and a $70 \%$ relative humidity.

Transmission electron microscopy (TEM). Top fragments of red pepper main roots after $14 \mathrm{~d}$ of growth of the control plants and treated with $20 \mathrm{mg} \mathrm{AlCl}_{3} \times \mathrm{dm}^{-3}$ were fixed in a fixative containing $2 \%$ paraformaldehyde and $2.5 \%$ glutaraldehyde buffered at $\mathrm{pH} 7.4$ in $0.1 \mathrm{M}$ cacodylate buffer. Fixation was performed at room temperature for two hours, followed by $12 \mathrm{hr}$ at $4^{\circ} \mathrm{C}$. When fixed, the samples were rinsed with $0.1 \mathrm{M}$ cacodylate buffer at $4^{\circ} \mathrm{C}$ for $24 \mathrm{hr}$ and then treated with $1 \% \mathrm{OsO}_{4}$. Subsequently, the samples were transerred to re-distilled water and stained with a 0.5 aqueous solution of urany acetate. After passage through increasing concentrations of propylene oxide in ethanol and finally through pure propylene oxide, the samples were embedded for $12 \mathrm{hr}$ in Spurr Low Viscosity resin at $70^{\circ} \mathrm{C}$. Ultrathin sections (60nm thick) were treated with a $8 \%$ solution of uranyl acetate in acetic acid and with lead citrate. The images were observed and recorded using the Tesla BS-500 electron microscopy.

\section{RESULTS}

An analysis of electronograms from the longitudinal sections of the apical region of the red pepper root showed that the cap cells of the control plants were characterised by the presence of a centrally located nucleus with one or two nucleoli and a varied number of small vacuoles. Mitochondria, Golgi bodies, smooth and rough endoplasmic reticulum (ER), many ribosomes and amyloplasts, filled with small starch grains, also occurred in the cells (Figs 1,2).

In the presence of $20 \mathrm{mg} \times \mathrm{dm}^{-3} \mathrm{AlCl}_{3}$, the cytoplasm of the cap cells seen in TEM was characterised by the occurrence of organelles which in many cases had an altered structure (Figs 3, 4). The amyloplasts contained a smaller number of starch grains, but with much larger sizes compared to the control (Fig. 3). In the small vacuoles of the cap cells, the occurrence of dark, electron-dense, spherical-like formations was found (Fig. 3), which were also observed by using light microscopy. Numerous mitochondria were characterised by the electron brighter matrix, as well as a reduced number of cristae and often degenerating contents (Fig. 4).
In the control object, the dividing cells in the meristem region were surrounded by a thin cell wall, and their protoplast, in addition to a nucleus, contained proplastids, mitochondria, Golgi bodies, ER, numerous ribosomes and small vacuoles (Figs 5,6).

On the other hand, the cells of the meristematic tissue of the plants treated with aluminum $\left(20 \mathrm{mg}_{\times} \mathrm{dm}^{-3}\right.$ $\mathrm{AlCl}_{3}$ ) were distinguished by the presence of small, but more numerous, vacuoles containing electron-opaque formations (Figs 7, 8), similar to those described in the vacuoles of the cap. The lobate cell nuclei had irregular, folded contours with deep invaginations (Fig. 8), and at some place a partial degradation of the nucleus membrane occurred (Fig. 9).

The occurrence of swelling mitochondria showing destructive changes, similar to those in the root cap, as well as the bursting of the membrane of these organelles, was also found (Figs 9, 10).

Moreover, the cell walls were marked by varied thickness or undulation. The formation of two walls in close vicinity was also observed (Figs 11, 12).

\section{DISCUSSION}

The increased aluminum concentration induced numerous disorders in the cell ultrastructure of roots of red pepper cv. 'Trapez'. These changes prove the high sensitivity of the studied cultivar to aluminum toxicity, which is confirmed by earlier results obtained by $\mathrm{K} \mathrm{o}-$ $\mathrm{n}$ a r s k a (2004a) relating to the index of tolerance (IT) for the root system of this cultivar. Less numerous and enlarged grains of statolith starch occurring in the cap of the plants treated with aluminum could be related to the disturbed positive geotropism of the roots and their hook-like curvature, which was observed in earlier studies by K o n a r s k a (2004b, 2005).

The destruction of plasmatic membranes of many organelles, observed in the study, could also result from the formation of permanent bonds of ions of the toxicant with proteins and phospholipids composing these membranes, which was described by other researchers (Cha and Lee, 1996; Li u et al. 1996). Anomalies in the structure of mitochondria, noted in the study, could be related to the disorders in phosphorus uptake and its deficiency, many times observed in experiments with aluminum (Holopainen et al. 1992; Malkanthi et al. 1999).

Electron-opaque bodies, the presence of which was found in the vacuoles of cells of the root at its different levels, were probably aluminum deposits. Such form of their deposition is reported by other researchers (Clune and Copeland, 1999; Mangabeira et al. 1999; Vázquez et al. 1999). In the vacuoles, aluminum ions may be bound by organic acids or phosphorus (M a and $\mathrm{Hiradate}, 2000$; Yang et al. 2000), silicon (Vázquez et al. 2002) or 
tannins (S to u tjes dijk et al. 2001). But in literature we find reports on the deposition of aluminum deposits also in cell nuclei ( $\mathrm{Sil} v \mathrm{v}$ et al. 2000) and cell walls (Craw ford and Wilkens, 1997; Horst et al. 1999; Schmohl and Horst, 2001), which is confirmed by research of the present paper's author.

Also, the conducted study does not unequivocally confirm changes in the number of dictyosomes and vesicles of Golgi bodies or disorders in the structure and number of endoplasmic reticulum tubules, which were described by other authors ( $\mathrm{C}$ r a w ford and Wil k e n s, 1997; Clune and Copeland, 1999).

\section{REFERENCES}

Bennet R. J., 1998. The aluminum response network in wheat (Triticum aestivum L.). I. The root growth reactions. S. Afr. J. Plant Soil, 15 (1): 38-45.

Brauner L., Bunkatsh F. 1987. Praktikum z fizjologii roślin. PWN, Warszawa.

Budiková S., 1999. Structural changes and aluminum distribution in maize root tissues. Biol. Plant. 42 (2): 259-266.

Cha D. H., Lee D. K. 1996. Effects of different aluminum levels on growth and root anatomy of Alnus hirsuta Rupr. seedlings. J. Sustainable Forestry, 3 (2-3): 45-63.

Clune T. S., Copeland L., 1999. Effects of aluminum on canola roots. Plant Soil, 216; 27-33.

Crawford S. A., Wilkens S., 1997. Ultrastructural changes in root cap cells of two australian native grass species following exposure to aluminum. Aust. J. Plant Physiol. 24: 165-174.

De Lima M. L., Copeland L., 1994. Changes in the structure of the root tip of wheat following exposure to aluminum. Aust. J. Plant Physiol. 21: 85-94.

Holopainen T., Anttonen S., Wulff A., Palomäki V., Kärenlampi L., 1992. Comparative evaluation of the effects of gaseous pollutants, acidic deposition and mineral deficiencies: structural changes in the cells of forest plants. Agric. Ecosystems Environ. 28: 185-189.

Horst W. J., Schmohl N., Kollmeier M., Baluška F., Sivaguru M., 1999. Does aluminum effect root growth of maize through interaction with the cell wall - plasma membrane - cytoskeleton continuum? Plant Soil, 215 (2): 163-174.

Konarska A., 2004a. Wpływ nadmiaru glinu na rozwój i budowę korzeni trzech gatunków roślin. / The influence of aluminum's on growth and root morphology of three plants species. J. Elementol. 9 (2): 109-118.

Konarska A., 2004b. Wpływ glinu i niskiego pH na rozwój i strukturę korzeni siewek słonecznika zwyczajnego w kulturach wodnych. / The influence of aluminum excess on grown and root structure of sunflower. Pamiętnik Puławski, 138: 77-88.

Konarska A., 2005. Changes in development and structure of Raphanus sativus L. var. radicula Pers. root under aluminum stress condition. Acta Sci. Pol. Hortorum Cultus 4 (1): 85-97.
Liu D., Wang W., Jiang W., 1996. Effects of aluminum ions on root growth and nucleoli in root tip cells of mung bean (Phaseolus radiatus L.). Chin. J. Appl. Environ. Biol. 2 (3): 254-258.

Ma J. F., Hiradate S., 2000. Form of aluminum for uptake and translocation in buckwheat (Fagopyrum esculentum Moench). Planta, 211: 355-360.

Malathi N., Sarethy I.P., Paliwal K., 2001. Effect of aluminum on hydroponically grown Acacia nilotica seedlings. J Plant Biol. 28 (1): 105-109.

Malkanthi D. R. R., Yokoyama K., Yoshida T., Moritsugu M., Matsushita K., 1995. Effect of low pH and Al on growth and nutrient uptake of several plants. Soil Sci. Plant Nutr. 41 (1): 161-165.

Mangabeira P., Mushrifah I., Escaig F., Laffray D., Franca M. G., Galle P., 1999. Use of MISS microscopy and elektron probe X-ray microanalysis to study the subcellural localization of aluminum in Vicia faba root cells. Cell Mol. Biol. 45 (4): 413-422.

Michałek W. J., 2002. Fizjologiczne aspekty tofsyczności mono- i polimerycznej formy glinu na przykładzie sałaty (Lactuca sativa L.). / Physiological aspects of toxicity of the mono- and polymeric form of aluminum on the example of lettuce (Lactuca sativa L.). Rozprawy Naukowe AR w Lublinie, zeszyt 259.

Pan J., Zhu M., Chen H. 2001. Aluminum - induced cell death in root - tip cells of barley. Envir. Exp. Bot. 46: 71-79.

Schmoh1 N., Hor st W. J., 2001. Cell - wall composition modulates aluminum toxicity. $14^{\text {th }}$ International Plant Nutrition Colloquium, Hannover, Germany 2001: 262-263, 14 ref.

Silva I. R., Smyth T. J., Moxley D. F., Carter T. E., A1len N. S., Rufty T. W., 2000. Aluminum accumulation at nuclei of cells in the root tip. Fluorescence detection using lumogallion and confocal laser scanning microscopy. Plant Physiol. 123: 543-552.

Sivaguru M., Baluška F., Volkmann D., Felle H. H., Horst W. J., 1999. Impact of aluminum on the cytoskeleton of the maize root apex. Short - term effects on the distal part of the transition zone. Plant Physiol. 119: 1073-1082.

Stoutjesdijk P. A., Sale P. W., Larkin P. J., 2001. Possible involvement of condensed tannins in aluminum tolerance of Lotus pedunculatus. Aust. J. Plant Physiol. 28: 1063-1074.

Szatanik-Kloc A., 1999. The influence of aluminium on morphological and anatomical features in wheat and triticale. / Wpływ glinu na cechy morfologiczne oraz anatomiczne pszenicy i pszenżyta. Zbiór Prac Ogólnopol. Konf. Nauk.: Fizyczna degradacja gleb: prognozowanie, metody ochrony i rekultywacji. Lublin, 9 IX 1999. Polskie Towarzystwo Agrofizyczne: 132-136.

Tabuchi A., Matsumoto H., 2001. Changes in cell-wall properties of wheat (Triticum aestivum) roots during aluminum - induced growth inhibition. Physiol. Plant. 112: 353-358.

Vázquez M. D., Poschenrieder Ch., Corrales I., Barceló J., 1999. Change in apoplastic aluminum during the imitial growth response to aluminum by roots of a tolerant maize variety. Plant Physiol. 119 (2): 435-444. 
Vázquez, M. D., 2002. Aluminum exclusion mechanism in root tips of maize (Zea mays L.): lysigeny of aluminum hyperaccumulator cells. Plant Biol. 4 (2): 234-249.

Weryszko-Chmielewska E., Michońska M., Chwil M., Szadura M., 1999. Destrukcja tkanek korzeni dwóch odmian lędźwianu siewnego (Lathyrus sativus L.) w warunkach stresu glinowego. / Destruction of root tissues of two cultivar of chickling vetch (Lathyrus sativus L.) by aluminum excess. Ann. UMCS, sect. EEE, 7: 71-79.

Weryszko-Chmielewska E., Chwil M., 1998. Rozwój korzeni grochu zwyczajnego (Pisum sativum L.) w warunkach stresu glinowego i silnego zakwaszenia środowiska. / The development of roots of pea (Pisum sativum L.) under the conditions of aluminum stress and strong acidification of the environment. Zesz. Probl. Post. Roln. 456: 629-636.

Wenzl P., Patiño G.M., Chaves A. L., Mayer J. E., Rao I. M., 2001. The high level of aluminum resistance in signal grass is not associated with known mechanisms of external aluminum detoxification in root apices. Plant Physiol. 125 (3): 1473-1484.

Yang Z. M., Sivaguru M., Horst W., Matsumoto H., 2000. Aluminum tolerance is achieved by exudation of citric acid from roots of soybean (Glycine max). Physiol. Plant. 110 (1): 72-77.

\section{Zmiany w ultrastrukturze korzeni siewek Capsicum annuum $\mathrm{L}$. w warunkach stresu glinowego}

\section{Streszczenie}

Badano wpływ glinu na ultrastrukturę komórek korzenia czternastodniowych siewek papryki rocznej 'Trapez' uprawianych w kulturach wodnych. Zaburzenia struktury komórek obserwowano w transmisyjnym mikroskopie elektronowym (TEM). Analiza podłużnych przekrojów wierzchołkowej strefy korzeni roślin kontrolnych wykazała, że komórki czapeczki i komórki strefy merystematycznej miały układ i kształt typowy dla tych stref korzenia, a organella komórkowe były prawidłowo wykształcone.

Zmiany w strukturze komórek pod wpływem glinu polegały na redukcji liczby ziaren skrobi w leukoplastach czapeczki, tworzeniu płatowatych jąder oraz redukcji liczby cystern w diktiosomach, a także uszkodzeniu membran komórkowych. Zaobserwowano ponadto pęcznienie mitochondriów przy jednoczesnym zmniejszaniu się liczby grzebieni mitochondrialnych lub pękaniu otoczki tych struktur. W wakuolach badanego odcinka korzenia stwierdzono obecność licznych nieprzejrzystych elektronowo tworów o pokaźnych rozmiarach, będących najprawdopodobniej depozytami glinu. Ściana komórkowa była często zgrubiała, pofałdowana lub obserwowano tworzenie się dwu ścian w bliskim sąsiedztwie. Uzyskane wyniki świadczą o dużej wrażliwości badanej odmiany papryki na stres glinowy. 